\title{
Pembelajaran Bermuatan HOTS (Higher Order Thinking Skill) di Jurusan Tadris Bahasa Indonesia
}

\author{
Indrya Mulyaningsiha1 ${ }^{\mathrm{a}}$ dan Itaristantia ${ }^{2}$
}

${ }^{a}$ IAIN Syekh Nurjati Cirebon

${ }^{1}$ indrya.mulyaningsih@syekhnurjati.ac.id; ${ }^{2}$ itaristanti@yahoo.com

Article info

Article history:

Received: 31-07-2018

Revised : 12-11-2018

Accepted: 12-12-2018

Keywords:

activities

HOTS

Indonesia

learning

performances

\section{A B S T R A C T}

This qualitative descriptive study aims to describe learning with HOTS content for students as prospective teachers. The study population consisted of all lecturers and students of the Indonesian Department of Social Sciences FITK IAIN Syekh Nurjati Cirebon. The research sample included: 4 lecturers and 117 students. Data was collected through questionnaires, interviews, and observations. The results of the study indicate that learning in the Indonesian Department of Social Sciences has been loaded with HOTS. However, there are still characteristic institutions and faculties that have not been charged with HOTS. Therefore, it should be necessary to improve the lecturers who are characteristic of the Institute and Faculty. Learning courses that characterize the Department have carried out HOTS activities. The course characterization bills are not only in the form of papers, but products. These products can be enjoyed by the general public, both in the form of performances and books.

Penelitian deskriptif kualitatif ini bertujuan untuk mendeskripsikan pembelajaran bermuatan HOTS bagi mahasiswa sebagai calon guru. Populasi penelitian terdiri atas semua dosen dan mahasiswa Jurusan Tadris Bahasa Indonesia FITK IAIN Syekh Nurjati Cirebon. Adapun sampel penelitian, meliputi: 4 dosen dan 117 mahasiswa. Data dikumpulkan melalui angket, wawancara, dan pengamatan. Adapun hasil penelitian menunjukkan bahwa pembelajaran di Jurusan Tadris Bahasa Indonesia sudah bermuatan HOTS. Namun demikian, masih terdapat mata kuliah penciri Institut dan Fakultas yang belum bermuatan HOTS. Oleh karena itu, hendaknya perlu ada perbaikan bagi para dosen pengampu mata kuliah penciri Institut dan Fakultas. Pembelajaran mata kuliah penciri Jurusan sudah melakukan aktivitas HOTS. Tagihan mata kuliah penciri Jurusan tidak hanya berupa makalah, tetapi produk. Produk tersebut dapat dinikmati oleh masyarakat umum, baik berupa pementasan maupun buku.

Copyright @ 2018 Institut Agama Islam Negeri Syekh Nurjati Cirebon. All rights reserved.

\section{PENDAHULUAN}

Berdasarkan data yang dirilis oleh OECD (The Organisation for Economic Cooperation and Development), hasil evaluasi PISA (Programme for International Students 


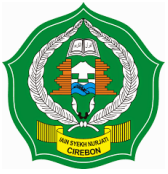

$$
\begin{gathered}
\text { Indonesian Language Education and Literature } \\
\text { e-ISSN: 2502-2261 } \\
\text { http://www.syekhnurjati.ac.id/jurnal/index.php/jeill/ } \\
\text { Vol. 4, No. 1, Desember 2018, } 114 \text { - } 128
\end{gathered}
$$

Assessment) tahun 2015 menempatkan Indonesia berada di urutan 61 dari 70 negara di dunia. Hasil PISA Indonesia berada di atas Brasil dan di bawah Jordania dengan perolehan skor science 403, reading 397, dan Mathematics 386 (https://www.oecd.org/pisa/). Seperti telah diketahui bersama, PISA merupakan evaluasi yang dilakukan pada beberapa negara. Evaluasi ini dapat berupa tes maupun kuisoner. Evaluasi dilakukan kepada murid berumur 15 tahun. Pertama kali PISA dilaksanakan pada tahun 2000 dan berulang setiap tiga tahun. Adapun evaluasi yang dilakukan meliputi adalah sains, membaca, dan matematika. Rendahnya capaian PISA Indonesia tidak terlepas dari peran pengajar atau guru. Bila selama ini murid dibiasakan dengan evaluasi berbasis HOTS (Higher Order Thinking Skill), dapat dipastikan perolehan PISA Indonesia akan lebih baik. Hal ini dibuktikan oleh Singapura yang menduduki urutan pertama dengan skor masing-masing 556, 535, dan 564. Sebelumnya, Singapura juga berada di urutan bawah. Namun Pemerintah Singapura berusaha keras dengan terus melatih dan meningkatkan kemampuan literasi para muridnya. HOTS merupakan kemampuan berpikir tingkat tinggi. Guru-guru di Indonesia belum membiasakan diri menggunakan HOTS. Hal ini dapat dibuktikan dengan pembelajaran yang lebih mengedepankan hafalan. Peran guru sangat penting dalam menjadikan murid memiliki kemampuan berpikir tingkat tinggi. Jurusan Tadris Bahasa Indonesia Fakultas Ilmu Tarbiyah dan Keguruan IAIN Syekh Nurjati merupakan lembaga pencetak calon guru, terutama guru Bahasa Indonesia. Oleh karena itu, mahasiswa Jurusan Tadris Bahasa Indonesia harus memahami, menguasai, dan dapat mempraktikkan HOTS.

Permendikbud Nomor 23 Tahun 2015 mengamanatkan pembiasaan membaca bagi seluruh siswa di Indonesia. Pembiasaan ini dilakukan secara berkala dan sebagai bagian dari pembentukan karakter. Literasi dalam Kamus Besar Bahasa Indonesia Edisi V memiliki arti kemampuan menulis dan membaca. Education Development Center (dalam Syahid, 2017), literasi dimaknai sebagai kemampuan yang dimiliki individu dalam kemampuan membaca, baik teks maupun konteks serta menggunakannya dalam kehidupan sehari-hari. UNESCO (2006) menyinonimkan literasi dengan melek huruf yang artinya keterampilan kognitif, membaca, dan menulis, baik berupa teks maupun konteks. Oleh karena itu, literasi merupakan inti dari pendidikan. Melalui literasi, seseorang dapat mengerti informasi yang diterima (UNESCO, 2006). Literasi juga dimaknai sebagai 


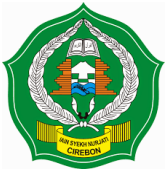

\section{Indonesian Language Education and Literature \\ e-ISSN: 2502-2261 \\ http://www.syekhnurjati.ac.id/jurnal/index.php/jeill/ \\ Vol. 4, No. 1, Desember 2018, 114 - 128}

praktik dan interaksi sosial yang berhubungan dengan pengetahuan, bahasa, dan budaya (Teguh, 2017).

Tim Pengembang Nasional (2017) mengklasifikasi komponen literasi, meliputi: literasi dini, literasi dasar, literasi perpustakaan, literasi media, literasi teknologi, dan literasi visual. Literasi dini merujuk pada kemampuan menyimak, bahasa lisan, dan berkomunikasi melalui gambar berdasarkan pengalaman dalam berinteraksi dengan lingkungan sosial atau di rumah. Literasi dasar merujuk pada kemampuan menyimak, berbicara, membaca, menulis, serta berhitung. Kemampuan berhitung ini dikaitkan dengan analisis untuk memperhitungkan, mempersepsikan, mengomunikasikan, serta menggambarkan informasi berdasarkan pemahaman dan simpulan secara pribadi. Literasi perpustakaan merujuk pada Kemampuan membedakan bacaan fiksi dan nonfiksi, memanfaatkan koleksi referensi dan periodikal, memahami pengklasifikasian pengetahuan dalam menggunakan perpustakaan, memahami penggunaan katalog dan pengindeksan untuk menyelesaikan berbagai keperluan. Literasi media merujuk pada kemampuan untuk membedakan berbagai bentuk media dan memahami tujuan penggunaannya. Literasi teknologi merupakan kemampuan memahami, memanfaatkan, serta mengelola teknologi dalam menyelesaikan permasalahan hidup. Literasi visual merupakan gabungan antara literasi media dan literasi teknologi. Keduanya mengembangkan kemampuan belajar dengan memanfaatkan materi visual dan audiovisual secara kritis dan bermartabat. Penafsiran terhadap materi visual, baik dalam bentuk cetak, auditori, maupun digital disebut teks multimodal. Teks multimodal ini harus dikelola dengan baik (Nasution, 2013). Demi mewujudkan kemampuan literasi maka Pemerintah mencanangkan Gerakan Literasi Sekolah (GLS). Pengertian Literasi Sekolah dalam konteks GLS adalah kemampuan mengakses, memahami, dan menggunakan sesuatu secara cerdas melalui berbagai aktivitas, seperti: membaca, melihat, menyimak, menulis, dan atau berbicara (Retnaningdyah, 2016). Hal ini selaras dengan tuntutan keterampilan membaca pada abad 21, yakni kemampuan memahami informasi secara analitis, kritis, dan reflektif (Dirjendikdasmen, 2016). Oleh karena itu, perlu dilaksanakan pendidikan literasi yang melibatkan: interpretasi, kolaborasi, konvensi, pengetahuan kultural, pemecahan masalah, refleksi dan refleksi diri, serta penggunaan bahasa (Kern, 2000). 


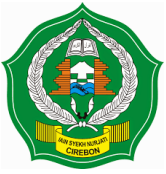

Indonesian Language Education and Literature

e-ISSN: 2502-2261

http://www.syekhnurjati.ac.id/jurnal/index.php/jeill/

Vol. 4, No. 1, Desember 2018, 114 - 128

HOTS kependekan dari Higher Order Thinking Skills atau diterjemahkan dengan kemampuan berpikir tingkat tinggi. HOTS mengukur kemampuan dalam: 1) transfer konsep, 2) memroses dan menerapkan informasi, 3) mengaitkan berbagai informasi yang berbeda, 4) menyelesaikan masalah dengan menggunakan informasi, dan 5) menelaah ide dan informasi secara kritis. Anderson \& Krathwohl (2001) mengklasifikasi dimensi proses kognitif sebagai berikut. HOTS mengharuskan pembelajar untuk memanfaatkan informasi dan gagasan dengan cara mengubah makna dan implikasinya. Hal ini seperti ketika pembelajar menggabungkan fakta dan gagasan kemudian menyintesis, menggeneralisasi, menjelaskan, memberi hipotesis, atau menyimpulkan (Newman dan Wehlage, 2013). HOTS dimaknai sebagai kemampuan dalam menggunakan pikiran untuk menyelesaikan masalah yang dihadapi (Onosko \& Newmann, 1994). Oleh karena itu, seseorang harus memahami, menafsirkan, menganalisis, serta menginterpretasi informasi. HOTS juga mengajarkan seseorang untuk kritis dalam mengevaluasi informasi, membuat simpulan, serta membuat generalisasi. Dalam Taksonomi Bloom revisi, HOTS merupakan kemampuan kognitif pada tingkat penerapan, analisis, evaluasi, dan inovasi.

Penelitian riset dan pengembangan yang dilakukan oleh Wardany, Sajidan, dan Ramli (2015) menunjukkan bahwa sebagian besar tes dalam buku Biologi SMA di Surakarta mencerminkan Kemampuan Berpikir Tingkat Rendah (LOTS). Hasil penelitian Pratiwi dan Fasha (2015) menunjukkan bahwa keterampilan HOTS hanya 20\% membentuk sikap disiplin siswa. Penelitian ini mengembangkan instrumen penilaian Fisika dengan menggunakan metode R\&D. Hasilnya menunjukkan bahwa semakin tinggi keaktifan siswa maka akan semakin tinggi pula keterampilan berpikir tingkat tinggi (HOTS) yang dimiliki. Pengaruh HOTS terhadap sikap disiplin hanya di bawah $20 \%$. Adapun persamaan dengan penelitian yang akan dilakukan, yakni pada observasi terhadap pembelajaran di Jurusan Tadris Bahasa Indonesia Fakultas Ilmu Tarbiyah dan Keguruan IAIN Syekh Nurjati Cirebon. Yuniar, Rakhmat, dan Saepulrohman (2015) meneliti penggunaan HOTS (High Order Thinking Skills) pada soal objektif tes dalam mata pelajaran Ilmu Pengetahuan Sosial (IPS) kelas V SD Negeri 7 Ciamis. Hal ini dilakukan karena masih banyaknya soal yang tidak memenuhi kriteria pembuatan soal. Terdapat sebelas keterampilan berpikir kritis yang masuk pada kelompok HOTS (High Order 


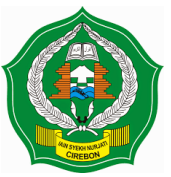

$$
\begin{gathered}
\text { Indonesian Language Education and Literature } \\
\text { e-ISSN: 2502-2261 } \\
\text { http://www.syekhnurjati.ac.id/jurnal/index.php/jeill/ } \\
\text { Vol. 4, No. 1, Desember 2018, } 114 \text { - } 128
\end{gathered}
$$

Thinking Skills), yakni: 1) memfokuskan pada pertanyaan, 2) menganalisis argumen, 3) mempertimbangkan yang dapat dipercaya, 4) mempertimbangkan laporan observasi, 5) membandingkan simpulan, 6) menentukan simpulan, 7) mempertimbangkan kemampuan induksi, 8)menilai, 9) mendefinisikan konsep, 10) mendefinisikan asumsi, dan 11) mendeskripsikan. Adapun metode penelitian yang digunakan adalah metode penelitian deskriptif dengan pendekatan kualitatif. Penelitian yang akan dilakukan memiliki persamaan pada metode dan pendekatannya. Ke-11 keterampilan tersebut juga akan digunakan dalam menganalisis soal yang selama ini digunakan di MTs. Penelitian Lindawati, Saregar, dan Yuberti (2016) bertujuan untuk menghasilkan Produk Instrumen Authentic Assessment untuk mengukur Higher Order Thinking Skills (HOTS) Peserta Didik Kelas X pada Mata Pelajaran Fisika SMA/MA materi suhu dan kalor. Produk yang dihasilkan, meliputi: 1) dimensi kognitif berupa tes esai yang mencakup $\mathrm{C} 4$, C5, dan C6; 2) dimensi psikomotor dan afektif berupa lembar observasi dengan indikator HOTS. Pada tahap kelima penelitian $R \& D$ ini dilakukan validasi produk oleh delapan dosen ahli dan tiga pendidik SMA/MA. Pada peneltian ini melibatkan banyak validator.

\section{METODE}

Penelitian ini merupakan penelitian deskriptif kualitatif. Tahap yang harus dilalui adalah tahap penjaringan data, tahap analisis data, dan tahap penyajian hasil analisis data. Sumber data adalah seluruh mahasiswa dan dosen Tadris Bahasa Indonesia. Dosen berjumlah tujuh orang. Sementara itu, mahasiswa berjumlah 186 orang dengan rincian: angkatan 2015/2016 berjumlah 36 orang, angkatan 2016/2017 berjumlah 72 orang, dan angkatan 2017/2018 berjumlah 78 orang. Data dijaring dengan menggunakan metode observasi dan wawancara. Adapun sampel penelitian 117 mahasiswa. Observasi dilakukan secara terencana dan terkontrol (Cohen, et al, 2000: 271). Kegiatan observasi dilengkapi dengan lembar atau blanko dan daftar isian yang telah dipersiapkan sebelumnya. Observasi dilakukan pada saat pembelajaran. Sementara itu, metode wawancara dilakukan dengan teknik cakap bertemu muka dan teknik angket/kuesioner. Teknik lanjutan dari metode wawancara bertemu muka adalah teknik rekam dan catat. Angket diberikan kepada mahasiswa dan dosen. Validitas instrumen penelitian dilakukan dengan penilaian pakar. 

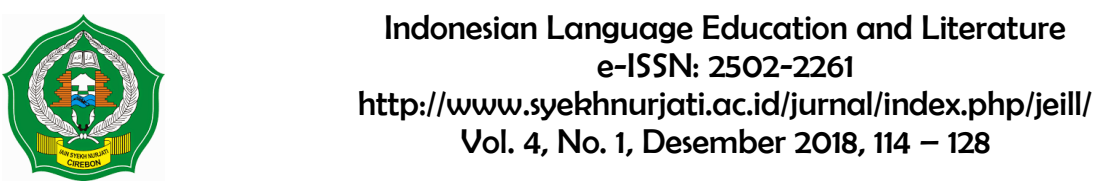

Validitas data ditempuh dengan triangulasi sumber, triangulasi metode, triangulasi peneliti, dan triangulasi teori (Moleong, 2010: 330). Dosen sebagai triangulasi sumber. Triangulasi metode dilakukan dengan mengecek kebenaran metode berdasarkan teori metode penelitian. Triangulasi peneliti dilakukan dengan diskusi teman sejawat. Triangulasi teori dilakukan dengan pendapat para ahli. Tahap penyajian analisis data dilakukan dengan menggunakan model interaktif Miles and Huberman (Sugiyono, 2012: 246-247). Adapun tahapan yang dilakukan: data reduction, data display, dan conclusion. Peneliti mengumpulkan data lalu menganalisis data tersebut. Begitu terus diulang sampai tidak lagi menemukan data baru.

\section{HASIL DAN PEMBAHASAN}

Responden penelitian ini sebanyak 117 dengan rincian: semester tiga (51), semester lima (34), semester tujuh (32). Berdasarkan jenis kelamin: 90 perempuan dan 27 laki-laki. Berdasarkan hasil angket, berikut ini daftar mata kuliah yang disukai oleh mahasiswa. Data tersebut menunjukkan bahwa "Sejarah dan Teori Sastra" adalah mata kuliah yang paling sukai. Adapun mata kuliah diurutan kedua adalah "Apresiasi Drama" dan selanjutnya "Sosiolinguistik". Hasil wawancara menunjukkan bahwa ketiga mata kuliah tersebut dikemas dengan santai sehingga mahasiswa merasa nyaman. Walupun santai, mata kuliah tersebut tetap meminta tagihan berupa produk. Salah satu produk yang dihasilkan adalah pementasan drama. Mahasiswa dibagi menjadi tiga kelompok. Setiap kelompok membuat naskah drama lalu dipentaskan. Pementasan dilakukan di panggung profesional "Rara Santang" milik Dinas Pariwisata Kota Cirebon. Pada saat pementasan, mahasiswa juga menghadirkan orang tua dan atau sanak saudara. Hal ini tentu sangat membuat mahasiswa senang dan bahagia. Pembelajaran ini sudah bermuatan HOTS karena mahasiswa diminta untuk mengkreasi atau membuat naskah drama. Selain itu, mahasiswa juga diminta untuk mementaskan secara profesional. 

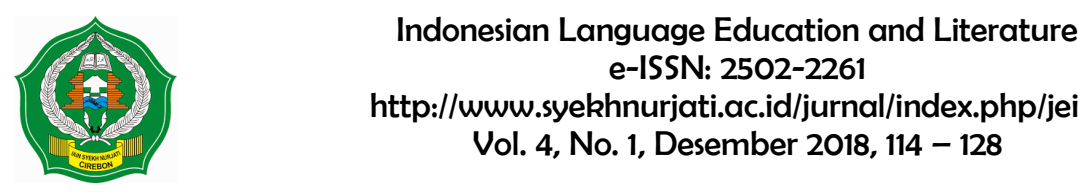

e-ISSN: 2502-2261

http://www.syekhnurjati.ac.id/jurnal/index.php/jeill/

Vol. 4, No. 1, Desember 2018, 114 - 128

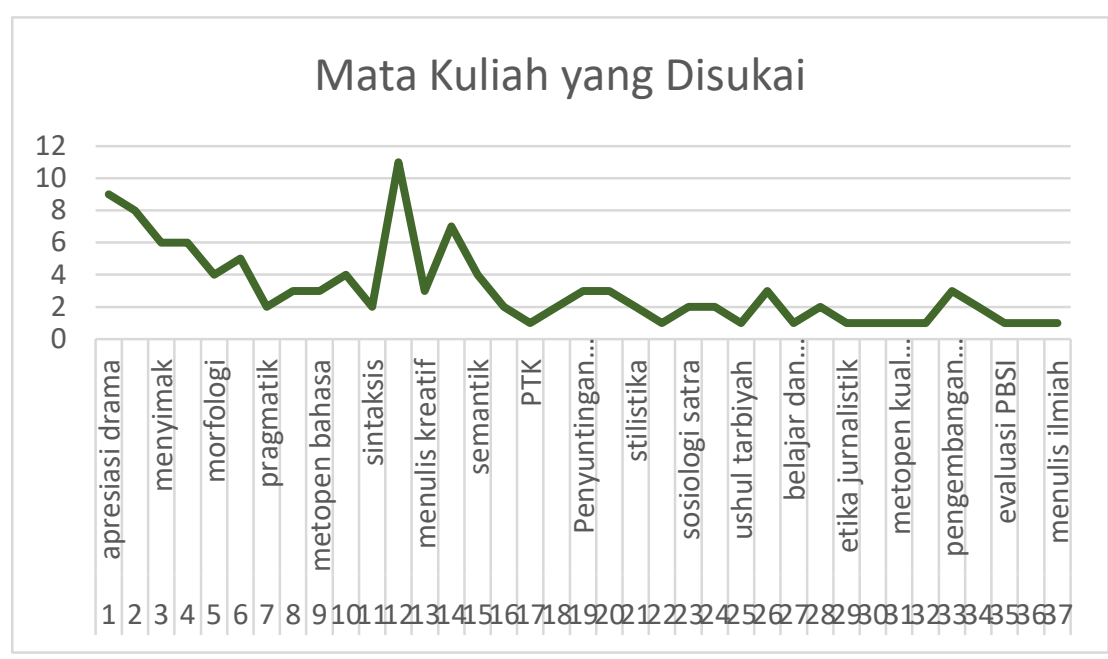

Gambar 1. Mata Kuliah yang Disukai

Namun demikian, ternyata pada mata kuliah di Jurusan Tadris Bahasa Indonesia (TBIn) masih ada yang meminta untuk hafalan, yakni 56\%. Setelah dikonfirmasi, mata kuliah yang meminta tagihan berupa hapalan adalah mata kuliah penciri Institut dan Fakultas. Di Jurusan TBIn memang terdapat tiga kelompok mata kuliah, meliputi: Institut, Fakultas, dan Jurusan. Adapun mata kuliah penciri Institut, antara lain: Quran dan Hadis. Mata kuliah penciri Fakultas, antara lain: Mashadir Tarbawiyah. Kedua mata kuliah tersebut meminta tagihan dalam bentuk hafalan. Hasil wawancara menunjukkan bahwa mahasiswa juga tidak menyukai mata kuliah ini karena membosankan dan berbentuk hafalan. Selain itu, latar belakang pendidikan mahasiswa Jurusan TBIn adalah umum sehingga mahasiswa mengalami kesulitan jika belajar mata kuliah yang banya menggunakan bahasa Arab. Walaupun sebenarnya, selama satu tahun, mahasiswa Jurusan TBIn sudah mendapat pembelajaran secara insentif untuk belajar bahasa Arab dan bahasa Inggris. Ternyata mahasiswa masih mengalami kesulitan. 


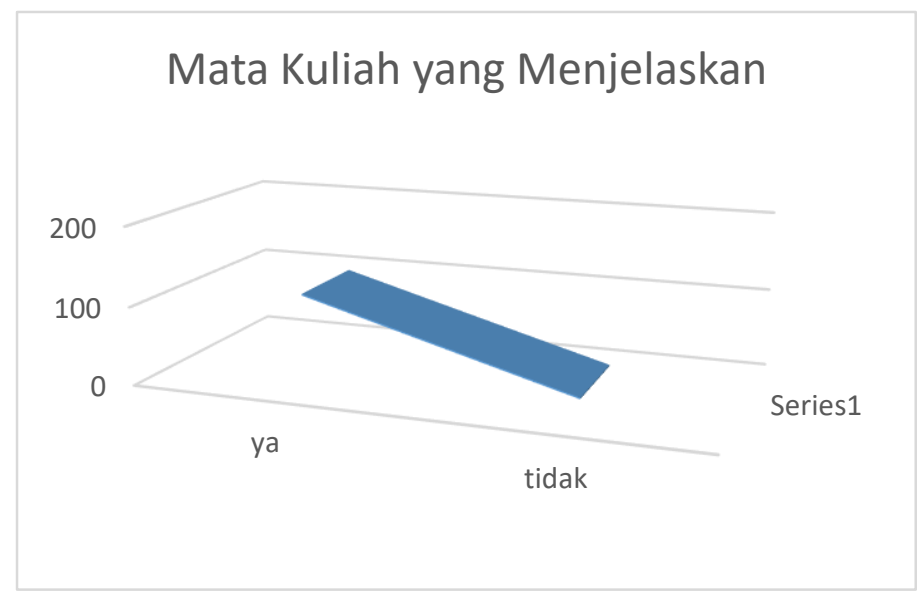

Gambar 2. Mata Kuliah yang Menjelaskan

Sesuai tingkatan pembelajaran dalam Taksonomi Bloom, di Jurusan TBIn juga terdapat mata kuliah yang meminta mahasiswa untuk menjelaskan. Artinya, pembelajaran meminta mahasiswa bukan hanya menghafal, tetapi juga menjelaskan. Angket menunjukkan 106 mahasiswa diminta untuk menjelaskan pada saat pembelajaran. Semua mata kuliah penciri Jurusan meminta mahasiswa melakukan ini. Pada saat pembelajaran, dosen akan meminta mahasiswa untuk menjelaskan ulang materi yang diberikan saat itu. Dosen juga meminta mahasiswa untuk bertanya lalu dijawab oleh mahasiswa lain. Pembelajaran di kelas lebih banyak aktivitas tanya jawab oleh mahasiswa. Dosen hanya mengoreksi jawaban yang tidak atau kurang tepat, serta menguatkan.

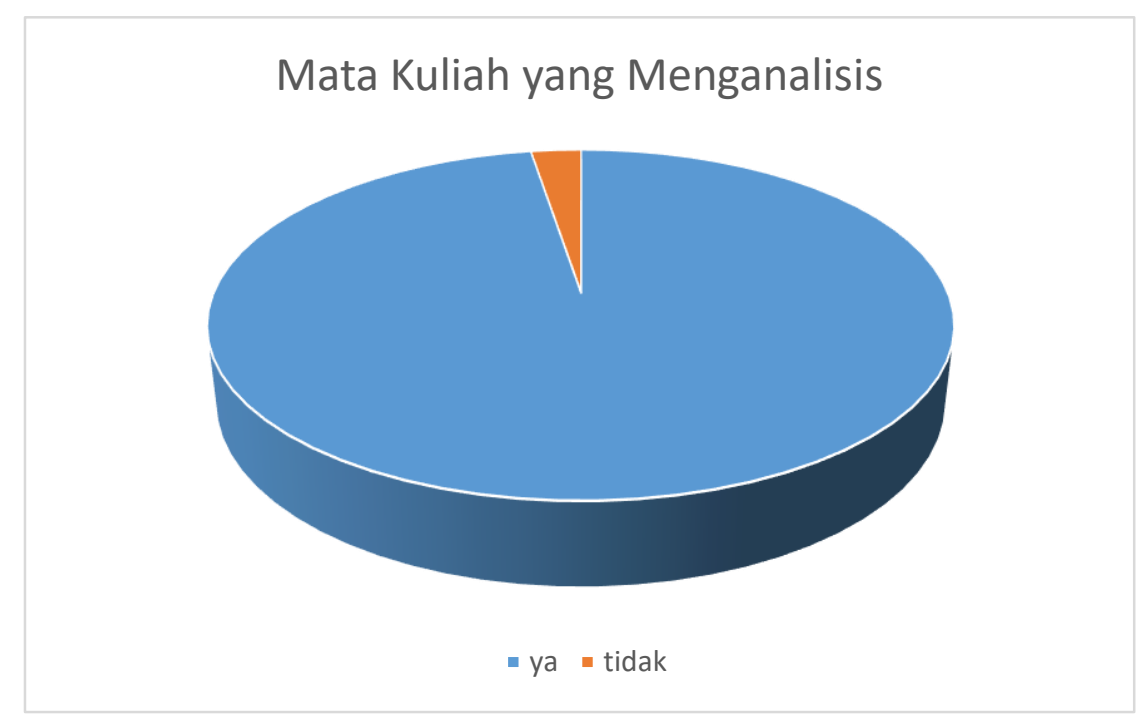

Gambar 3. Mata Kuliah yang Menganalisis 
Pembelajaran di Jurusan TBIn juga meminta mahasiswa melakukan analisis. Informasi ini diperoleh dari 113 mahasiswa. Data menunjukkan, hampir semua mata kuliah penciri Jurusan meminta mahasiswa untuk melakukan analisis. Analisis merupakan bagian penting dalam pembelajaran. Melalui kegiatan analisis, mahasiswa diminta untuk memahami, mengapresiasi, dan memberikan masukan. Mahasiswa dibiasakan untuk mampu menemukan sesuatu yang baru. Oleh karena itu, mahasiswa harus jeli dan teliti. Kemampuan menganalisis sangat diperlukan karena berawal dari hal tersebut akan diperoleh hal-hal baru yang selama ini mungkin belum banyak diketahui umum.

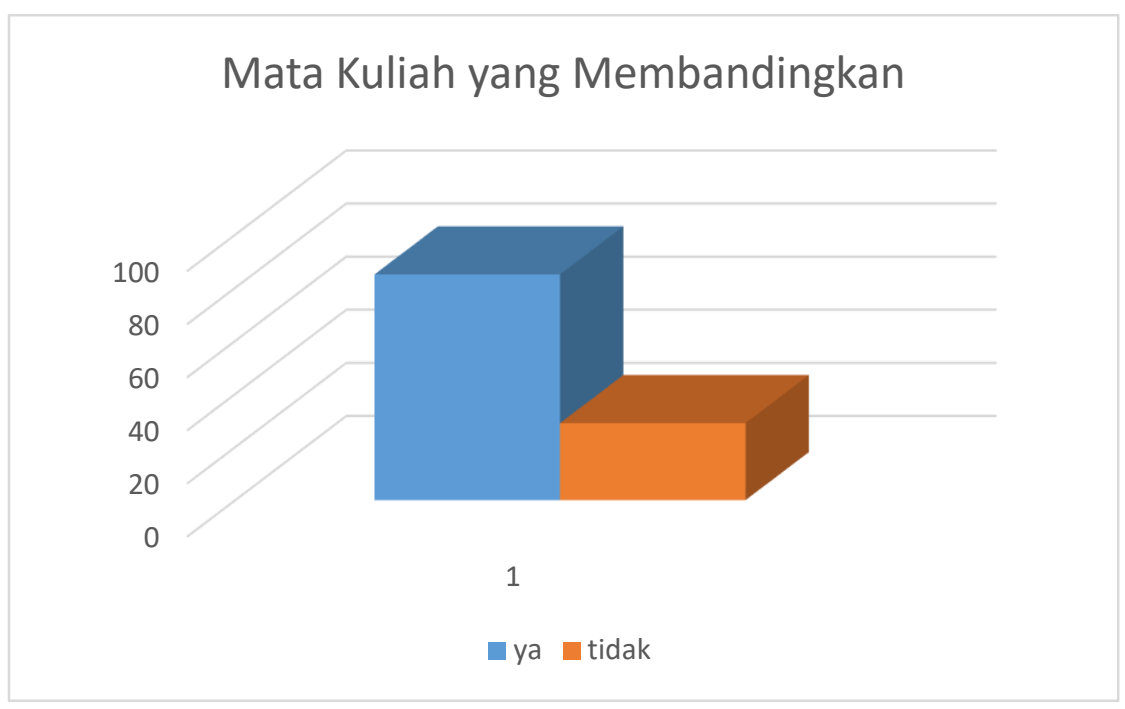

Gambar 4. Mata Kuliah yang Membandingkan

Tingkatan selanjutnya adalah membandingkan. Berdasarkan data yang terkumpul, semua mata kuliah Jurusan TBIn meminta mahasiswa untuk membandingkan. Artinya, mahasiswa diminta untuk membandingkan antara satu hal dengan hal lain. Mahasiswa juga diminta membandingkan antara ide satu dengan ide lain. Membandingkan merupakan aktivitas yang memerlukan pemahaman dan analisis. Adapun aktivitas pembelajaran biasanya sebagai berikut. Dosen memberikan tema tertentu lalu mahasiswa diminta membandingkan, misalnya antara Kurikulum KTSP dan Kurikulum 2013. Mahasiswa diminta membandingkan kedua Kurikulum tersebut dari berbagai sisi. Hasil analisis dibuat makalah lalu dipresentasikan. 


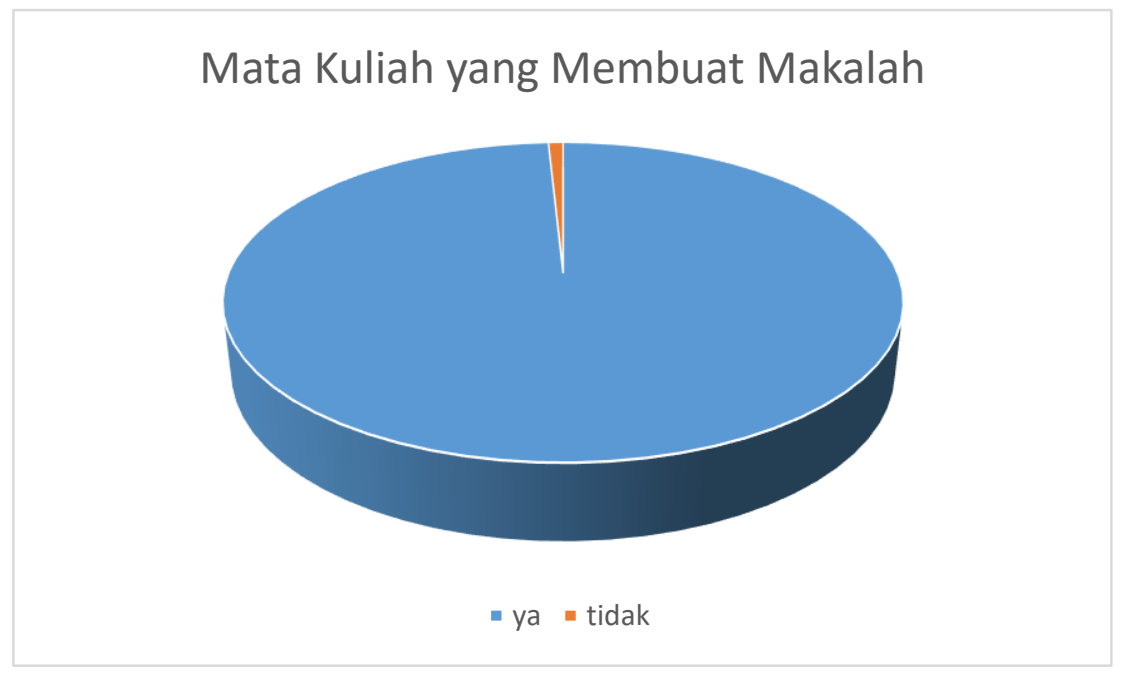

Gambar 5. Mata Kuliah yang Membuat Makalah

Data tersebut menunjukkan bahwa semua mata kuliah meminta mahasiswa untuk membuat atau menyusun makalah. Namun demikian, berdasarkan pengamatan dan wawancara dengan dosen dapat diketahui bahwa makalah yang ditulis oleh mahasiswa belum atau tidak layak disebut sebagai makalah. Makalah ini sebenarnya adalah kompilasi atau kumpulan pendapat orang lain. Hal ini karena makalah tersebut hanya memuat potongan pendapat dari orang lain yang kemudian ditulis ulang oleh mahasiswa. Bahkan pendapat tersebut tidak dilakukan parafrasa, tetapi sama persis dari sumber aslinya. Dalam makalah tersebut, mahasiswa belum melakukan analisis dan membandingkan. Mahasiswa yang mengkopi lalu menempelkan saja pendapat. Mahasiswa juga tidak mencantumkan sumber atau asal pendapat yang dikutip. Sebagian besar sumber pendapat yang ditulis berasal dari internet, terutama blog. Sementara telah diketahui bersama, bahwa penulis blog juga mengutip dari orang lain. Oleh karena itu, mahasiswa seharusnya merujuk atau mencari dan membaca dari buku aslinya. Aktivitas mahasiswa yang tidak merujuk pada buku asli dapat menyebabkan perbedaan pemahaman. Walaupun sebenarnya, hal ini jugalah yang menjadi alasan mahasiswa tidak membaca buku aslinya. Mahasiswa memiliki keterbatasan dalam memiliki buku tentang materi yang dibahas. Walaupun sebenarnya mahasiswa dapat meminjam di perpustakaan, tetapi ternyata hal tersebut jarang dilakukan. Mahasiswa lebih suka melihat di internet dan mengkopi dari milik orang lain. 


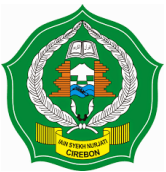

\section{Indonesian Language Education and Literature}

e-ISSN: 2502-2261

http://www.syekhnurjati.ac.id/jurnal/index.php/jeill/

Vol. 4, No. 1, Desember 2018, 114 - 128

Data lain yang terkumpul menunjukkan bahwa pembelajaran meminta mahasiswa untuk mempresentasikan makalah atau tugas yang dibuat. Dari 117 mahasiswa, 99,1\% mengatakan demikian. Adapun aktivitas yang dilakukan biasanya berupa diskusi kelompok. Mahasiswa dibagi menjadi beberapa kelompok. Setiap kelompok diberi satu tema sehingga tiap kelompok memiliki tema yang berbeda. Tema tersebut kemudian dibuat atau disusun menjadi sebuah makalah. Makalah kemudian dipresentasikan di kelas secara berkelompok. Dalam diskusi disediakan sesi tanya jawab atau diskusi. Beberapa teman dari kelompok lain akan mengajukan pertanyaan dan kelompok yang presentasi berkewajiban untuk menjawab. Dosen mengikuti dan menyimak secara penuh aktivitas kelompok ini. Hal ini dilakukan agar dosen dapat mengontrol dan mengoreksi jika terdapat jawaban-jawaban yang kurang tepat. Di akhir pertemuan, dosen akan memberi penegasan terkait materi yang dibahas. Cara belajar seperti ini sebenarnya sangat bermanfaat. Berdasarkan informasi dan pengamatan, sebagian besar mahasiswa jika bekerja berkelompok maka yang bekerja hanya beberapa orang saja. Mahasiswa lain hanya ikut ditulis namanya tanpa ikut membantu.

Pembelajaran dengan tagihan berupa makalah lalu dipresentasikan memiliki kelebihan dalam hal tambahan pengetahuan. Artinya, mahasiswa mau tidak mau harus banyak membaca, baik buku, jurnal, maupun tulisan lain. Apalagi beberapa dosen di Jurusan TBInd selalu memberi ketentuan bahwa referensi yang digunakan minimal 10, dengan tahun publikasi 5 - 10 tahun terakhir. Sumber harus dari buku dan atau jurnal. Referensi tidak boleh berasal selain dari kedua sumber tersebut. Namun demikian, masih saja mahasiswa kurang maksimal dalam mengerjakan. Bahkan untuk mata kuliah "Menulis Ilmiah", semua tulisan mahasiswa akan dicek similaritasnya dengan menggunakan aplikasi Plagiarism Checker X. Hal ini dilakukan sebagai salah satu upaya agar mahasiswa terbiasa dengan hal tersebut. Seperti telah jamak diketahui bahwa mahasiswa kadang melakukan tugas secara asal-asalan dan merupakan kopi tempel dari tulisan orang lain. Oleh karena itu, dengan diberlakukannya cek similaritas ini dapat sedikit memberi pengetahuan kepada mahasiswa tentang pentingnya menulis sendiri. Selama ini, batasan yang diberikan untuk hasil tes kesamaan adalah $15 \%$ termasuk daftar pustaka. 


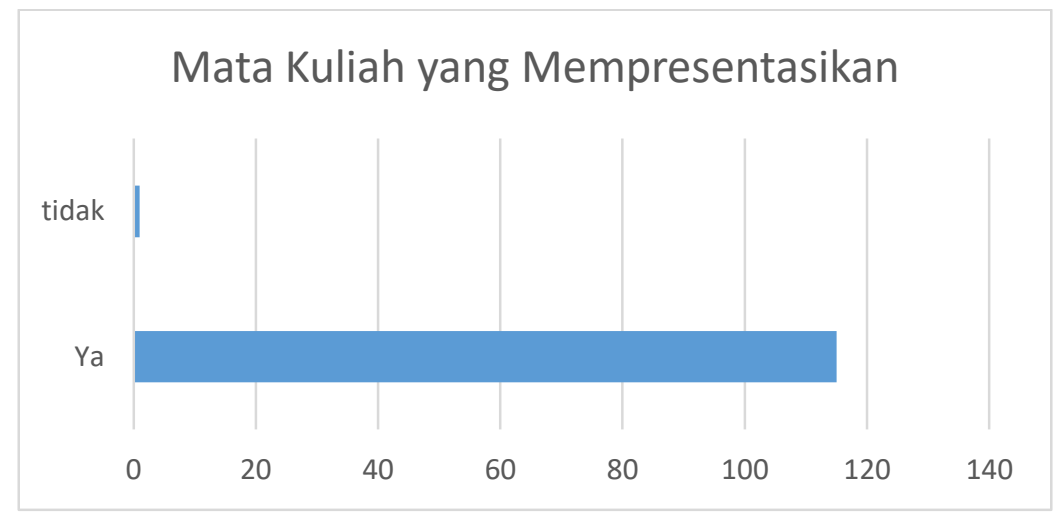

Gambar 6. Mata Kuliah yang Mempresentasikan

Selain seperti yang telah diuraikan di atas, beberapa mata kuliah juga membantu mahasiswa untuk menemukan sebuah rumus atau formula baru. Rumus yang dimaksud bukan layaknya rumus matematika, tetapi kreasi atau wujud dari mata kuliah yang sedang ditempuh. Misalnya pada mata kuliah Sosiolinguistik. Mahasiswa mendapat tagihan berupa menganalisis nama-nama di sebuah desa. Nama desa tersebut dianalisis berdasarkan kajian sosiolinguistik. Hasil nama-nama tersebut menjadi kumpulan topinimi, baik berupa nama, filosofi, maupun lainnya. Hal ini sangat menarik, mengingat penduduk di desa tersebut justru tidak terpikir untuk mendokumentasikan nama desa yang ditinggali. Demikian juga dengan mata kuliah "Pengembangan Evaluasi Pembelajaran". Tagihan mata kuliah ini adalah kumpulan soal, baik isian maupun pilihan ganda. Mahasiswa diberi tagihan, secara individu dan kelompok. Demi memudahkan koordinasi, mahasiswa dibagi menjadi sembilan kelompok, yakni: kelas 7, 8, 9, 10, 11, 12, baik SMA maupun SMK. Setiap kelompok berbagi tugas berdasarkan KD yang ada. Setiap KD membuat menjadi dua jenis soal, yakni: isian dan pilihan ganda. Setiap KD juga dibuat soal dengan memperhatikan tingkat kesulitan, yakni: mudah, sedang, dan sulit. Untuk soal pilihan ganda, mahasiswa harus mengujicobakan di sekolah. Hasil dari uji coba tersebut, dianalisis untuk mengetahui kualitas soal yang telah dibuat tersebut. Selanjutnya, soal-soal yang telah dibuat oleh mahasiswa dikumpulkan menjadi satu sehingga menjadi kumpulan soal. Bahkan terdapat satu cerita menarik bahwasannya soal yang dibuat oleh mahasiswa diminta oleh guru. Pada saat mahasiswa mengujicobakan soal tersebut, guru meminta soal 


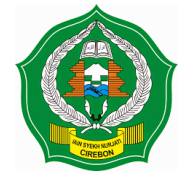

$$
\begin{gathered}
\text { Indonesian Language Education and Literature } \\
\text { e-ISSN: 2502-2261 } \\
\text { http://www.syekhnurjati.ac.id/jurnal/index.php/jeill/ } \\
\text { Vol. 4, No. 1, Desember 2018, } 114-128
\end{gathered}
$$

dan kunci jawabannya. Guru melakukan itu karena ingin menggunakan beberapa soal tersebut untuk ujian semester.

\section{Mata Kuliah yang Menemukan Rumus}

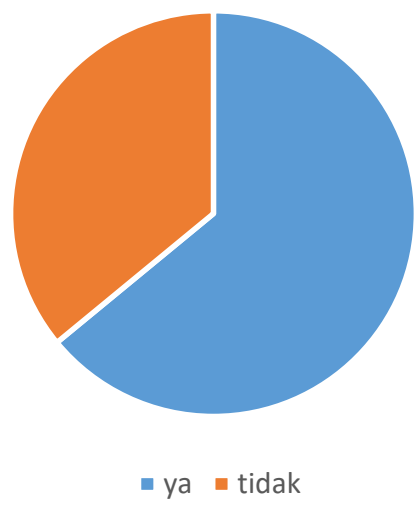

Gambar 7. Mata Kuliah yang Menemukan Rumus

\section{SIMPULAN}

Berdasarkan data dan analisis dapat disimpulkan bahwa pembelajaran di Jurusan Tadris Bahasa Indonesia sudah bermuatan HOTS. Namun demikian, masih terdapat mata kuliah penciri Institut dan Fakultas yang belum bermuatan HOTS. Oleh karena itu, hendaknya perlu ada perbaikan bagi para dosen pengampu mata kuliah penciri Institut dan Fakultas. Pembelajaran mata kuliah penciri Jurusan sudah melakukan aktivitas HOTS. Tagihan mata kuliah penciri Jurusan tidak hanya berupa makalah, tetapi produk. Produk tersebut dapat dinikmati oleh masyarakat umum, baik berupa pementasan maupun buku.

\section{DAFTAR PUSTAKA}

Anderson, L.W., dan Krathwohl, D.R. (2001). A Taxonomy for Learning, Teaching, and Assesing; A revision of Bloom's Taxonomy of Education Objectives. New York: Addison Wesley Lonman Inc.

Cohen, L., et al. (2000). Research Methods in Education. Great Britain: TJ International Ltd, Padstow, Cornwall.

Creswell, J. W. (2012). Qualitative Inquiry \& Research Design: Choosing among Five Approaches (4th ed.). Thousand Oaks, CA: Sage.

Dirjendikdasmen. (2016). Buku Saku Gerakan Literasi Sekolah. Jakarta: Kemendikbud. 


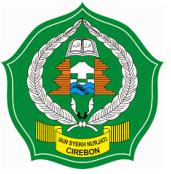

Kern, R. (2000). Literacy and Language Teaching. Oxford: Oxford University Press.

Lindawati, Siregar, A., dan Yuberti. (2016). "Pengembangan Instrumen Authentic Assessment untuk Mengukur Higher Order Thinking Skills Peserta Didik" dalam Seminar Nasional Pendidikan Program Studi Pendidikan Fisika Bandarlampung, IAIN Raden Intan Lampung, 28 Mei 2016, ISBN 978-602-74712-0-7, 140-149.

Moleong, L. J. (2010). Metode Penelitian Kualitatif. Edisi Revisi. Bandung: Remaja Rosdakarya.

Nasution. (2013). Berbagai Pendekatan dalam Proses Belajar Mengajar. Jakarta: Bumi Aksara.

Newman dan Wehlage. (2013). Authentic Education (daring) diakses di https://sites.ehe.osu.edu/bedmiston/files/2013/03/Authentic-Education-5-

Standards.pdf pada Selasa, 17 Oktober 2018 pukul 21.31 WIB.

Onosko, J. J., \& Newmann, F. M. (1994). Creating More Thoughtful Learning Environment. In J. Mangieri, \& C. C. Blocks (Eds.), Creating Powerful Thinking in Teachers and Students Diverse Perspectives (pp. 27-49). Forth Worth: Harcourt Brace College PublishersCohen, Louis, et al. 2012. Research Methods in Education. Great Britain: TJ International Ltd, Padstow, Cornwall.

Peraturan Menteri Pendidikan dan Kebudayaan No. 23 tahun 2015 tentang Penumbuhan Budi Pekerti.

Permendikbud Nomor 23 Tahun 2016 Tentang Standar Penilaian Pendidikan.

Pratiwi, U., dan Fasha, E. F. (2015). "Pengembangan Instrumen Penilaian HOTS Berbasis Kurikulum 2013 terhadap Sikap Disiplin dalam Jurnal Penelitian dan Pembelajaran IPA, 1(1), November 2015, 123-142 E-Issn 2477-2038.

Retnaningdyah, P., dkk. (2016). Panduan Gerakan Literasi Sekolah di Sekolah Menengah Pertama. Jakarta: Direktorat Pembinaan Sekolah Menengah Pertama Direktorat Jenderal Pendidikan Dasar dan Menengah Kementerian Pendidikan dan Kebudayaan.

Sugiyono. (2012). Metode Penelitian Kuantitatif Kualitatif dan R\&D. Bandung: Alfabeta.

Syahid, A. S. (2017). "Hati-hati Mengartikan, Gerakan Literasi Bukan Sekadar Gerakan Baca dan Tulis" dalam Kompasiana, 2 Maret 2017.

Teguh, M. (2017). “Aktualisasi Kurikulum 2013 di Sekolah Dasar melalui Gerakan Literasi Sekolah untuk Menyiapkan Generasi Unggul dan Berbudi Pekerti” Dalam Prosiding Seminar Nasional 15 Maret 2017, 18-26 di http://pgsd.umk.ac.id/files/prosiding/2017/3\%20Mulyo\%20Teguh.pdf.

Tim Pengembang Nasional. (2017). Pembekalan Fasilitator Nasional: Implementasi Program Pemerataan Guru dalam Meningkatkan Literasi di Sekolah Daerah $3 T$ (Terdepan, Terluar, dan Tertinggal). Jakarta: Direktorat Jendral Guru dan Tenaga Kependidikan, Kementerian Pendidikan dan Kebudayaan.

Undang-Undang Nomor 20 Tahun 2003 Tentang Sistem Pendidikan Nasional. 


$$
\begin{gathered}
\text { Indonesian Language Education and Literature } \\
\text { e-ISSN: } 2502-2261 \\
\text { http://www.syekhnurjati.ac.id/jurnal/index.php/jeill/ } \\
\text { Vol. 4, No. 1, Desember 2018, } 114-128
\end{gathered}
$$

UNESCO. (2006). Education for All Global Monitoring Report.

Wardany, K., Sajidan, dan Ramli, M. (2015). "Penyusunan Instrumen Tes Higher Order Thinking Skill Pada Materi Ekosistem SMA Kelas X" dalam Prosiding Seminar Nasional XII Pendidikan Biologi FKIP Universitas Sebelas Maret Surakarta, 538543.

Yuniar, M., Rakhmat, C., dan Saepulrohan, A. (2015). “Analisis HOTS (High Order Thinking Skills) Pada Soal Objektif Tes dalam Mata Pelajaran Ilmu Pengetahuan Sosial (IPS) Kelas V SD Negeri 7 Ciamis" dalam Prosiding Jurusan Pendidikan Guru Sekolah Dasar, FIP, Universitas Pendidikan Indonesia, 187-195. 